\title{
BRAZILIAN CONSUMERS' PERCEPTION OF TENDERNESS OF BEEF STEAKS CLASSIFIED BY SHEAR FORCE AND TASTE
} \author{
Helena Fillet Spoto ; Carmen Josefina Contreras Castillo ${ }^{4}$ \\ ${ }^{1}$ USP/ESALQ - Depto. de Zootecnia, C.P. 9 - 13418-900 - Piracicaba, SP - Brasil. \\ ${ }_{3}^{2} U S P / E S A L Q$ - Programa de Pós-Graduação em Ciência dos Alimentos. \\ ${ }^{3}$ USP/ESALQ - Depto. de Ciências Exatas. \\ ${ }^{4}$ USP/ESALQ - Depto. de Agroindústria, Alimentos e Nutrição. \\ *Corresponding author <efdelgad@esalq.usp.br>
}

Eduardo Francisquine Delgado ${ }^{1 *}$; Ana Paula Aguiar²; Edwin Moisés Marcos Ortega ${ }^{3}$; Marta

ABSTRACT: The knowledge of consumer perception of meat tenderness and taste is essential to forecast a Brazilian quality value-based beef market. This study aimed to verify perception of tender (WBSF $\leq 4.1$ $\mathrm{kg}$ ) from tough $(\geq 4.8 \mathrm{~kg}$ ) strip loin steak or uncharacteristic (calcium-treated/Ca-IM) and normal (noncalcium/NO-Ca) meat taste by consumers according to gender, age, education and income levels. Steaks were previously classified by shear force measurements as tender or tough. Each consumer was served a paired sample of one tender and of one tough steak, which were either Ca-IM or NO-Ca treated before tenderness classification. Three hundred and eight consumers answered a nine-point intensity (tenderness) and hedonic (taste) scales evaluation questionnaire. Among consumers, $82.2 \%$ indicated beef as first choice meat products, $75.3 \%$ had beef at least four times a week; $39.3 \%$ considered taste as the most important meat attribute and $30.2 \%$ considered tenderness; $75.8 \%$ were males; $73.6 \%$ were 21 to 55 years old; $56.7 \%$ had college education; $76.6 \%$ had monthly income higher than US $\$ 435,00$. Tender steaks were scored highest $(P<0.01)$, independently of gender, age and income. However, elderly consumers gave higher scores to tender steaks in comparison to middle age consumers $(P<0.05)$. In the lower education level, scores given to tender and tough meat did not differ. The higher income level responders assigned lower tenderness scores within tender or tough meat $(P=0.10)$. Differences in taste were perceived by both genders, and by consumers in every income and education level. Males gave higher scores (dislike less) within Ca-IM steaks. Consumers in the lower education level scored taste higher (like most) within untreated samples. The elderly people could not differentiate taste between the Ca-IM and NO-Ca steaks. These are the first indications that Brazilian consumers perceive tender from tough or uncharacteristic taste of beef, but palatability is evaluated differentially depending on gender, age, education and income level.

Key words: gender, age, education, income, calcium

\section{PERCEPÇÃO PELOS CONSUMIDORES BRASILEIROS DA MACIEZ DA CARNE CLASSIFICADA PELA FORÇA DE CISALHAMENTO E SABOR}

\begin{abstract}
RESUMO: O conhecimento da percepção de maciez e sabor da carne bovina pelo consumidor é essencial para vislumbrar um mercado brasileiro que pague por qualidade. Este estudo avaliou a percepção diferenciada de contra-filé macio (WBSF $<4.1 \mathrm{~kg}$ ) ou duro $(>4.8 \mathrm{~kg}$ ), ou ainda com sabor não característico (imersão em Ca/ Ca-IM) ou normal (sem cálcio/ NO-Ca) de acordo com sexo, faixa etária, e nível de escolaridade formal e renda dos consumidores. Os bifes foram pareados em amostras macia/dura e CaIM/NO-Ca, e servidos a 308 consumidores que responderam a um questionário apresentando escalas de intensidade (maciez) e hedônica (sabor) de nove pontos. O perfil dos consumidores mostrava que: $82,2 \%$ indicaram carne bovina como sua primeira escolha entre as carnes; 75,3\% consumiam carne bovina pelo menos quatro vezes por semana; $39,3 \%$ consideravam sabor como o atributo mais importante durante o consumo enquanto $30,2 \%$ indicavam maciez; 75,8\% eram do sexo masculino; 73,6\% tinham entre 21 e 55 anos; 56,7\% tinham alguma formação superior; 76,6\% com rendimento mensal maior que R\$ 1.000,00. De maneira geral, os bifes macios obtiveram notas mais altas $(P<0,01)$, independente de sexo, faixa etária e nível de renda. Entretanto, os idosos deram notas mais altas que os consumidores de meia idade em avaliações dos bifes macios $(P<0,05)$. No nível baixo de escolaridade não houve diferença nas notas
\end{abstract}


para bifes macios e duros. Quanto mais alto o nível de renda, menor foram as notas dadas nas avaliações dos bifes macios ou duros $(P=0,10)$. Diferenças no sabor foram notadas por ambos os sexos, e por todos os níveis de escolaridade e renda. O sexo masculino conferiu notas mais altas (desgostou menos) quando consumia bifes Ca-IM. Consumidores do menor nível de escolaridade atribuiram notas maiores para sabor (gostaram mais) em bifes com sabor normal. Os idosos não diferenciaram sabor entre os bifes Ca-IM e NO-Ca. Estas observações são as primeiras indicações objetivas de que os consumidores brasileiros são capazes de perceber diferenças entre bifes macios e duros ou com sabor amargo e normal. Todavia, a palatabilidade é avaliada de forma diferenciada dependendo do sexo, faixa etária, e níveis de escolaridade e renda.

Palavras-chave: sexo, faixa etária, escolaridade, renda, cálcio

\section{INTRODUCTION}

Meat attributes such as tenderness and taste are highly related to consumers overall acceptability and interferes with preference for beef. The importance of tenderness has been confirmed in US national audits (Savell et al., 1987; Morgan et al., 1991; Brooks et al., 2000) and warrants the choice of beef tenderness inconsistency as a major concern by the American beef industry (Savell \& Shackelford, 1992).

Several studies in other important beef-producing and consuming countries, have shown that consumers perceive differences in meat tenderness (Miller et al., 1995; Huffman et al., 1996; Boleman et al., 1997; Dransfield et al., 1998; Miller et al., 2001; Shackelford et al., 2001; Wheeler et al., 2002; 2004; Wyle et al., 2003). The consumers' perception of tender meat and the existence of a segment willing to pay premium prize for guaranteed tender steak are factors necessary for a quality value-based market (Boleman et al., 1997; Lusk et al., 2001). This market has potential to change the beef cattle producing system and to value competitive, efficient and technically prepared beef producers.

Brazil is an important beef producer and consumer, but data on consumer sensory evaluation of beef tenderness are scarce in the country. Consumers value meat flavor/taste as much as tenderness (Huffman et al., 1996; Neely et al., 1998; Egan et al., 2001; Umberger et al., 2002), and Brazilians whose eating habit involves consumption of meat from Bos indicus cattle, probably precluding tenderness appreciation, may be more interested in the flavor attribute. Therefore, it is important to know how consumers perceive those attributes of meat palatability to guide the beef industry whether and how to develop a system for beef quality and attend preferences at both internal and external markets. The aim of this study was to verify whether Brazilian consumers can perceive differences in meat tenderness and the importance of taste in their assessment of beef quality.

\section{MATERIAL AND METHODS}

Samples - To obtain a wide range of meat tenderness (Warner Bratzler shear force - WBS force), sixteen strip loin (Longissimus dorsi) samples were collected in two slaughter plants without any quality restraint yielding a product that represents their normal operation. The meat came from carcasses deboned 24 hours after slaughter, and upon arrival at the laboratory, was refrigerated and vacuum-packaged within 30 hours after slaughter. Half of the strip loin steaks were from old animals (cows) produced by a small meat plant. Since higher WBS force was expected in those samples, they were cut in $2.5 \mathrm{~cm}$ thick steaks and treated with $150 \mathrm{mM}$ of $\mathrm{CaCl}_{2}(\mathrm{Ca}-\mathrm{IM}=$ immersion in water solution for 36 hours at $4^{\circ} \mathrm{C}$ ). After treatment steaks were vacuum-packaged and stored at $4^{\circ} \mathrm{C}$ for four days. The second half of strip loins was from young males (label from the slaughter plant) and came from a medium-sized meat plant. Those samples were not treated with $\mathrm{CaCl}_{2}$ (NO-Ca), cut in $2.5 \mathrm{~cm}$-thick steaks, vacuum-packaged and conditioned for 14 to 21 days at $4^{\circ} \mathrm{C}$.

Tenderness classes - The day before each of the three consumer sensory tests, samples from $\mathrm{Ca}$ treated (7 days after slaughter) and untreated strip loins were prepared for WBS force measurements (AMSA, 1995). Three, $2.54 \mathrm{~cm}$-thick steaks from the cranial, medium and caudal end of strip loin samples were cut. Steaks were broiled in electric grill (Edanca) to a final temperature of $74^{\circ} \mathrm{C}$ (Novus Smart Meter thermocouple thermometer type $\mathrm{T}$ inserted into the geometric center of each steak). Cooked steaks were chilled for $10 \mathrm{~h}$ at $2^{\circ} \mathrm{C}$, and then ten cores per each steak $(1.27$ $\mathrm{cm}$ diameter) were removed parallel to the muscle fiber orientation Cores were sheared once on a Texture Test System (Food Technology Corporation) equipped with a Warner-Bratzler blade and $20 \mathrm{~cm} \mathrm{~min}^{-1}$ crosshead speed.

The samples from the same strip loins were then paired in tender/tough meat (Table 2), according to their WBS force. The arbitrary value of $4.5 \mathrm{~kg}$ was adopted as the threshold between tender and tough steaks, based on previous results with trained sensory panelists and research results done abroad. In pairs 1, 2, 3, 4 and 7, Ca-IM steaks were the tender sample; pairs 5, 6 and 8 had NO-Ca steaks as the tender samples. 
Taste classes - Ca-IM samples are prone to present bitter taste. This bitterness was consistently detected by the trained panelists (results not shown). Therefore, every consumer received a pair of samples with different taste: Ca-IM (bitter taste) and NO-Ca (characteristic taste) samples. Steaks were then assigned to evaluators so that either the tough class or the tender class was represented by a Ca-IM-treated steak, and that the remaining steak from each pair was from the NO-Ca-treated group.

Consumer sensory evaluation was performed in a consumer central location test in a booth at a national agribusiness fair (AGRISHOW 2004, Ribeirão Preto, SP) for three interjacent days. The paired tender/tough steaks were broiled to medium degree of doneness $\left(74^{\circ} \mathrm{C}\right.$ of internal temperature) on a grill with temperature adjusted to $163^{\circ} \mathrm{C}$. Two cubes of 1.2 $\times 1.2 \times 2.5 \mathrm{~cm}$ from each tenderness class were offered to the untrained consumers, so that each consumer evaluated only one pair of steaks. Samples were served in a random sequence just after broiling, in plastic plates randomly numbered (three digits). Consumers evaluated samples individually in tables with reserved, isolated space, under natural light. The evaluation ballot used was designed according to Miller (2003), with modifications. Primary questions were formulated in a 9-point, end anchored, intensity (1- tough; 9- tender) and hedonic (1- dislike extremely; 9- like extremely) scales for tenderness and taste, respectively. Open-ended secondary questions asked what the consumer liked and disliked in those samples regarding the two meat attributes defined in the primary questions. Complementary questions sought to understand the impact of gender, age, education level, and monthly income on consumer's sensory evaluation.

Statistical analysis was performed in a completely randomized design, assuming independence of the sample units. The statistical model for untrained consumer sensory scores included main effects of tenderness (tender and tough) and taste [uncharacteristic (Ca-IM) and characteristic (NO-Ca)]. Least square means were tested by Student's t test for paired samples; multiple comparisons of those main effects within gender, age, level of education were analyzed by Tukey test. The residual analysis and suppositions of the model were satisfied. Dependent variables were tested for significance by SPSS Software version 11 (2001).

\section{RESULTS AND DISCUSSION}

Demographics and consumption habits Sampled consumers do not represent the average Bra- zilian demographics standard (Table 1). However, these data are the first draft of objective evaluation for the perception Brazilian consumers have on beef.

About $82.2 \%$ of the evaluators had beef as their first choice meat; $75.3 \%$ consumed beef at least four times a week; $85.2 \%$ valued appearance of the meat or wholesomeness of the retailer; $33.9 \%$ were

Table 1 - Brazilian demographics and population sampled in the fair.

\begin{tabular}{|c|c|c|c|}
\hline Characteristic & & Brazil* & Fair \\
\hline \multicolumn{4}{|l|}{ Gender } \\
\hline & Woman & 51.7 & 24.2 \\
\hline & Man & 48.3 & 75.8 \\
\hline \multicolumn{4}{|c|}{ Age (years old) } \\
\hline & Up to 20 & 25.8 & 17.8 \\
\hline & 21 to 35 & 30.0 & 39.3 \\
\hline & 36 to 55 & 28.4 & 34.3 \\
\hline & $>55$ & 15.8 & 8.6 \\
\hline \multicolumn{4}{|c|}{ Education level } \\
\hline & Elementary & 67.3 & 11.4 \\
\hline & Middle & 22.9 & 31.9 \\
\hline & College & 8.8 & 56.7 \\
\hline \multicolumn{4}{|c|}{ Income (US\$ month $\left.{ }^{-1}\right)$} \\
\hline & Up to $435^{\#}$ & 88.2 & 23.4 \\
\hline & 436 to 2174 & 9.2 & 51.2 \\
\hline & Over 2174 & 1.3 & 25.4 \\
\hline
\end{tabular}

*Source: IBGE, 2003 (data from population over 10 years-old; education level was computed considering: elementary $=1$ to 8 years, middle $=9$ to 11 years, college $=$ over 12 years of formal education; Income considered only the economically active population); ${ }^{\#} \mathrm{US} \$ 1.00=\mathrm{R} \$ 2.30$.

Table 2 - Pairs of steaks offered to consumer sensory evaluation with WBS force measurement of the tender and tough samples.

\begin{tabular}{lccc}
\hline Pair (steaks) & $\mathrm{N}^{*}$ & Tender & Tough \\
\hline & & 3.9 & 4.8 \\
1 & 23 & 4.1 & 5.1 \\
2 & 31 & 3.5 & 5.0 \\
3 & 47 & 3.2 & 4.8 \\
4 & 49 & 3.6 & 5.3 \\
5 & 41 & 3.8 & 5.9 \\
6 & 14 & 4.1 & 6.6 \\
7 & 68 & 3.8 & 6.3 \\
8 & 27 & \multicolumn{3}{l}{} \\
$* \mathrm{~N}=$ Number of untrained consumers receiving the samples from \\
the pair for sensory evaluation.
\end{tabular}


used to buy only the most valuable retail cuts (hindquarter); $83.4 \%$ preferred at least medium-broiled beef; $66.7 \%$ lived in a two to four-persons household; and $39.3 \%$ considered taste as the most important meat attribute while $30.2 \%$ considered tenderness as their favorite attribute.

Obviously, those numbers also do not ordinarily represent the national scenario. However, the Brazilian beef consumer that would be part of a quality value-based meat market, which is probably better represented by small families composed by young people of higher education and income level, was closely sampled, except for the gender differences. In other countries it has been determined that younger people, smaller families and higher household income increase the probability to purchase high-quality meat (Quagrainie et al., 1998).

Tenderness - Tender meat received the highest scores within the pairs offered to the untrained consumers (Figure 1). Even when steaks presented small WBS differences, e.g. pair 1, consumers were able to score differently $(P=0.11)$. Regarding the other pairs, except for pairs 6 and 7, higher scores were always $(P<0.01)$ registered for the 'tender' beef, independently whether it came from Ca-IM or NO-Ca-treated strip loin steaks.

The lack of perception of tenderness differences between steaks of pair 7 could be related to the higher variability found in texture within steaks with high WBS force (Dugan \& Aalhus, 1998), which would certainly cause higher variation in the given scores since this is a confounding factor in the evaluation (Figure 1). The use of tender samples with WBS force superior to $4.0 \mathrm{~kg}$ could also decrease the proportion of consumer satisfied with its tenderness (Huffman et al., 1996; Miller et al., 2001). Even though

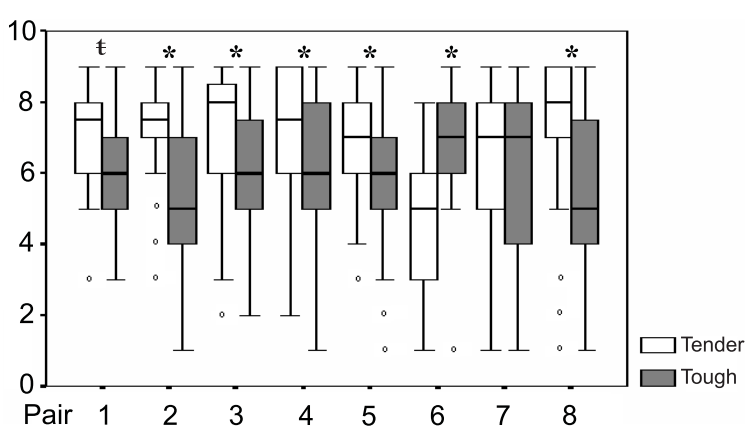

Figure 1 - Box plots for tenderness intensity scores (1- extremely tough; 9- extremely tender) of the eight pairs of strip loin steaks used for consumer sensory evaluation. ${ }^{\circ}$ Adjacent and outside values; - Inside box $=$ median value. Statistical differences between means within pair: ${ }^{\mathfrak{t}} P=0.11$; * $P<0.01$. results were obtained from a very small number of consumers evaluating the samples, there is no explanation for the higher scores given to the tough and bitter meat of pair 6 .

Perception of tenderness differences are somehow unexpected considering that WBS force values registered for most pairs of steaks (Table 2) would represent a tenderness transition point between slightly tender and slightly tough meat; a $4.0 \mathrm{~kg}$ force can be considered as threshold value (Huffman et al., 1996; Boleman et al., 1997; Miller et al., 2001) within a milieu of limits in the literature, ranging from $3.0 \mathrm{~kg}$ to $5.5 \mathrm{~kg}$ (Johnson et al., 1990; Miller et al., 1993; McKeith et al., 1985). Actually, scores given to most pairs of steaks $(2,3,4,5,6$ and 7$)$ as rated by trained panelists for tenderness evaluation, classified the strip loin samples in that threshold point (results not shown). However, the use of WBS force values resulting from different institutions to set thresholds of tenderness has to be taken with caution, once not only results obtained by different laboratories even using the same meat samples and standardized method can vary considerably (Wheeler et al., 1997), but also expected regional (cultural background) differences reflect the importance given to tenderness and its perception by consumers (Savell et al., 1987; Neely et al., 1998).

Taste - Bitterness has been observed in some works done with $\mathrm{CaCl}_{2}$ injection or immersion (Morgan et al., 1991; Pérez et al., 1998). Although taste hedonic evaluation by untrained consumers showed a wide distribution of scores (Figure 2), there was a consistent perception of taste differences.

Consumer characterization and sensory evaluation - In regard to consumer gender, both males and females were able to differentiate $(P<0.01)$ tender from tough or bitter from normal taste meat (Fig-

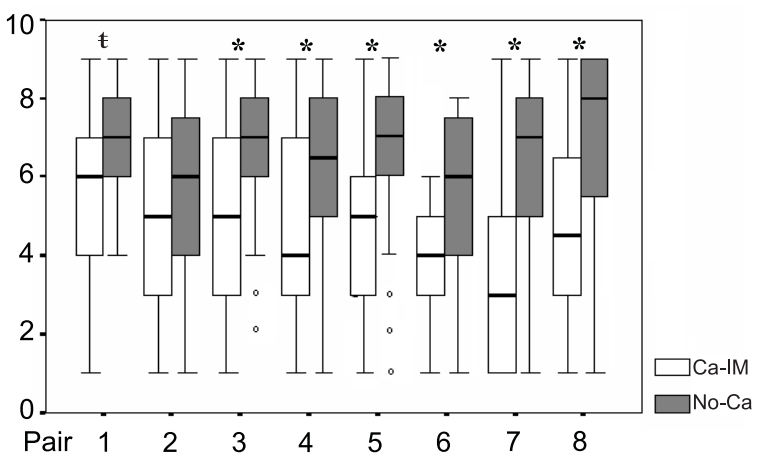

Figure 2 - Box plots for taste hedonic scores (1- dislike extremely; 9 - like extremely) by consumers of eight pairs of strip loin steaks used for consumer sensory evaluation. ${ }^{\circ}$ Adjacent and outside values; - Inside box = median value. Statistical differences between means within pair: ${ }^{\mathrm{t}} P<0.02 ; * P<0.01$. 
ure 3). However, males gave higher scores $(P<0.02)$ when rating Ca-IM steaks, suggesting they are more tolerant to uncharacteristic beef taste than females. One partial explanation may be related to the greater interest for taste aspects of foods shown by females (Roininen et al., 1999). Although it has been reported that females show greater appraisal for tender beef, confirmed by their willingness to pay more than males for guaranteed tender steak (Lusk et al., 2001), this study did not confirm objectively that appraisal, since no differences between gender were registered in the scores given to tender or tough steaks.

Tenderness Score

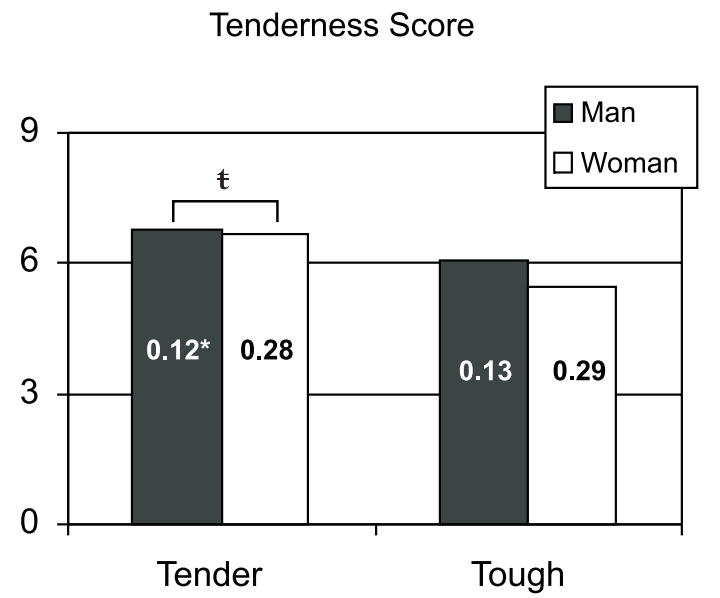

Older ( $>55$ years old) consumers scored tenderness $(P<0.05)$ higher than the middle-aged (36 to 55 years old) consumers within tender meat samples (Figure 4). However, all consumers were able to discern tender from tough beef within age classes. It has been reported that with increasing age, consumers are more likely to prefer tender meat (Lusk et al., 2001), but young consumers choose larger quantities of steaks of slightly less acceptable quality (Dransfield, 1997). The same attitude is herein depicted Brazilian consumers: higher requirement for tenderness and lower scores by the middle age con-

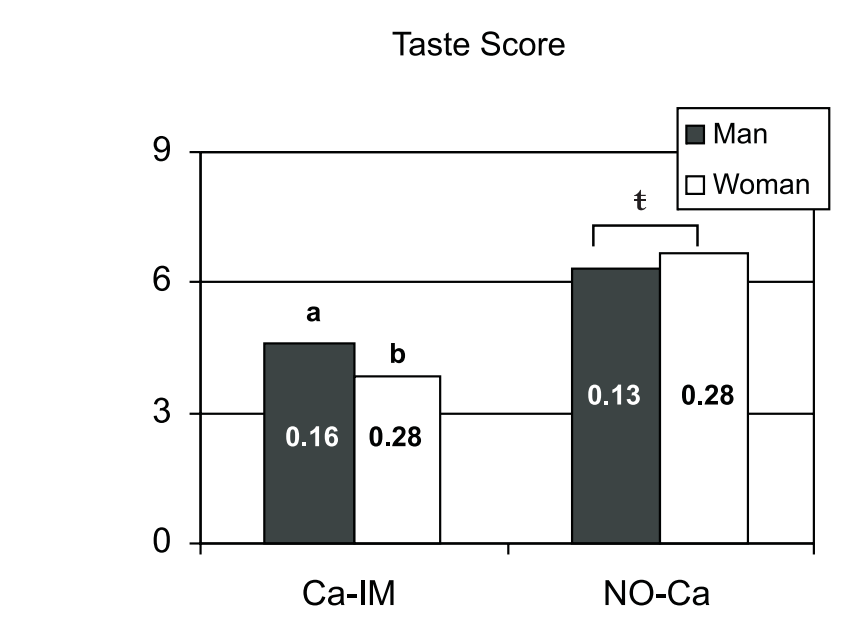

Figure 3 - Gender effect on consumer tenderness ( 1 = extremely tough; $9=$ extremely tender $)$ and taste scores $(1=$ dislike extremely; $9=$ like extremely) of strip loin varying in tenderness and taste. Tenderness $=$ Tender $(\leq 4.1 \mathrm{~kg})$ and Tough $(\geq 4.8 \mathrm{~kg})$; Taste $=\mathrm{Ca}-\mathrm{IM}$ steaks $\left(\right.$ Bitter) and NO-Ca (Normal); ${ }^{\text {t} S t a t i s t i c a l ~ d i f f e r e n c e s ~ i n ~ t h e ~ s c o r e s ~ g i v e n ~ t o ~ T e n d e r ~ a n d ~ T o u g h ~ o r ~}$ Bitter and Normal samples within gender $(P<0.03) ;{ }^{\text {a,b }}$ Different letters mean statistical difference within Bitter samples between gender $(P=0.02)$; Number of untrained consumers in the sensory evaluation (231 Men; 74 Women) ; Numbers inside bars are Standard Error of Mean.
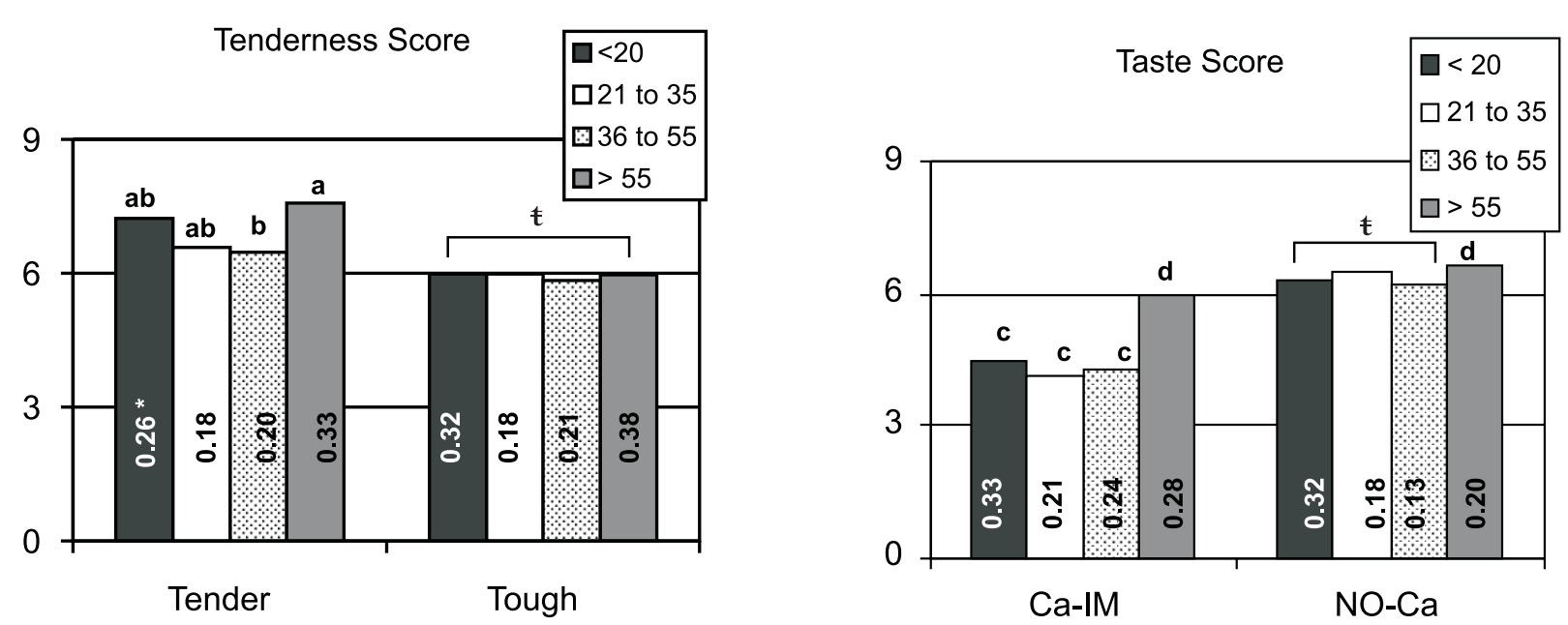

Figure 4 - Age effect on consumer tenderness $(1=$ extremely tough; $9=$ extremely tender $)$ and taste scores $(1=$ dislike extremely; $9=$ like extremely) of strip loin varying in tenderness and taste. Tenderness $=$ Tender $(\leq 4.1 \mathrm{~kg})$ and Tough $(\geq 4.8 \mathrm{~kg})$; Taste = Ca-IM steaks (Bitter) and NO-Ca (Normal); ${ }^{\mathrm{t}}$ Statistical differences in the scores given to Tender and Tough or Bitter and Normal samples within age groups $(P \leq 0.03)$; ${ }^{\mathbf{a}, \mathbf{b}}$ Different letters mean statistical difference within Tender samples among age groups $(P<0.05)$; ${ }^{\mathbf{c}, \mathbf{d}}$ Different letters mean statistical difference in taste among age groups $(P<0.01)$; Number of untrained consumers in the sensory evaluation $(<20=54 ; 21$ to $35=119 ; 36$ to $55=104 ;>55=26)$; *Numbers inside bars are Standard Error of Mean. 
sumers, and no differences between older and younger $(<20$ and 21 to 35 years old $)$ consumers.

Elderly people may be less requiring consumers. This age group gave higher scores for taste within Ca-IM steaks compared to the other age groups, and also were not able to differentiate $(P=0.25)$ taste for the NO-Ca samples. Those findings probably reflect less efficient chewing related to dental health and/or changes in muscle strength after certain age (Fillion \& Kilcast, 2001), or could also be related to reduced oral sensory feedback, probably related with lower number of nerve endings, which causes loss of sensitivity to taste in older consumers (Tepper \& Stoerr, 1991; Kimura, 1992).

Education level was an important variable in consumer's ability to discern tender from tough meat (Figure 5). Consumers with lower education level (elementary) did not distinguish $(P=0.23)$ between samples with different WBS force. The tenderness might be of greater importance for highly educated consumers, reflecting their capability to perceive texture differences, which would confirm results that the higher the education level, more likely the consumers are to prefer tender steak (Lusk et al., 2001), or will be more critics giving lower tenderness scores than other education levels (Barham et al., 2003). These last authors also found that the highly educated people were more willing to pay a premium for guaranteed tender beef. These observations may also reflect a more affluent lifestyle resulted from greater income level and education, which allowed them to become accustomed to purchasing higher quality meat. Therefore, they would come to expect this quality attribute from their meat.

Consumers of all education backgrounds were more pleased $(P<0.01)$ with steaks not immersed in calcium solution. Even though they were not able to discern tenderness differences, consumers of the lower education level gave higher taste scores than moderate level consumers within beef of characteristic taste $(P<0.06)$, even though there was no differences with those consumers at college level. Apparently at lower education level beef taste plays a central role in meat appraisal. The possibility that consumer from lower education level might present difficulties to understand the 9-point scales of the questionnaire also can not be ruled out.

The similar appraisal for taste by consumers at elementary and college education level may result from the fact that most of the latter are young college students and professionals, which are in the age group that, as mentioned before, would prefer quantities instead of quality in terms of tenderness.

On the other hand, income level was not a variable that changed the evaluation of tenderness or characteristic beef taste; all classes were able to discern tender from tough or bitter from normal taste meat (Figure 6). However, within tenderness classes (tender or tough), higher income level consumers gave lower tenderness scores, not differing from intermediate level within tender samples or from lower level within tough samples. The explanation may be that most of low monthly income group were composed of college stu-
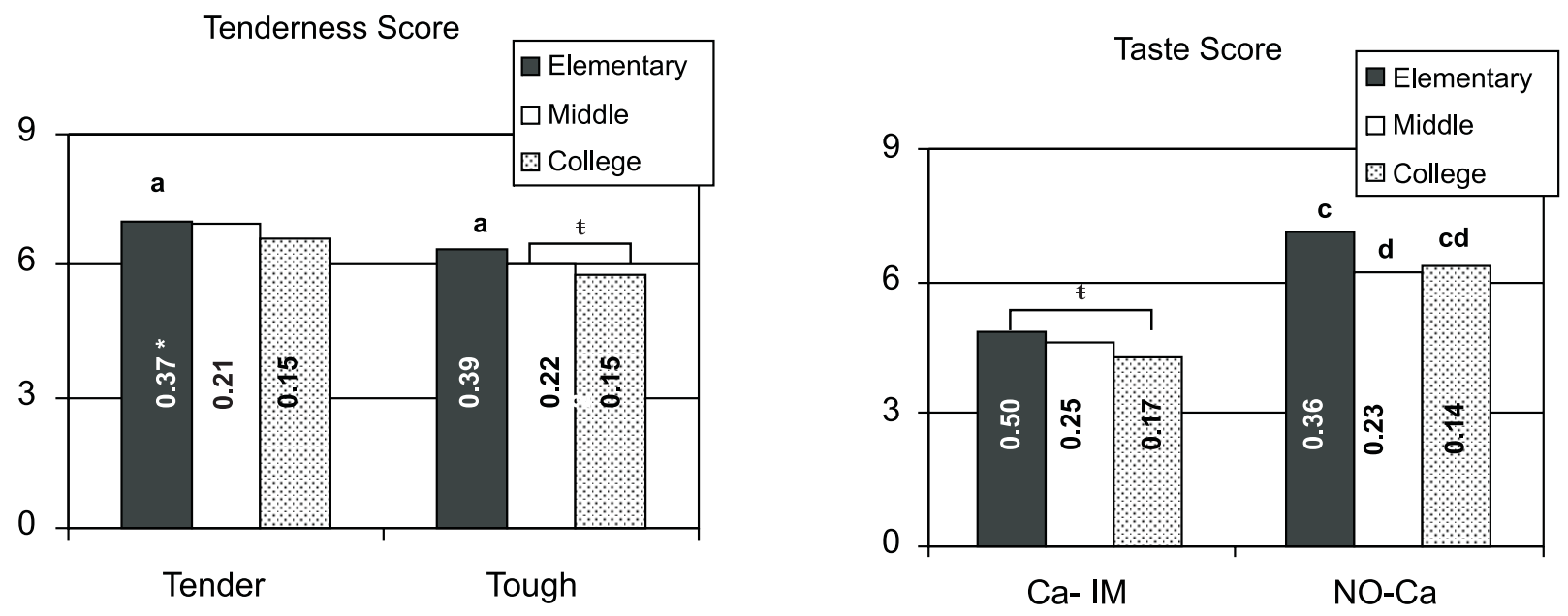

Figure 5 - Education level effect on consumer tenderness $(1=$ extremely tough; $9=$ extremely tender $)$ and taste scores $(1=$ dislike extremely; 9 = like extremely) of strip loin varying in tenderness and taste. Tenderness $=$ Tender $(\leq 4.1 \mathrm{~kg})$ and Tough $(\geq 4.8 \mathrm{~kg})$; Taste $=\mathrm{Ca}-\mathrm{IM}$ steaks (Bitter) and NO-Ca (Normal); ${ }^{\mathbf{t}}$ Statistical differences in the scores given to Tender and

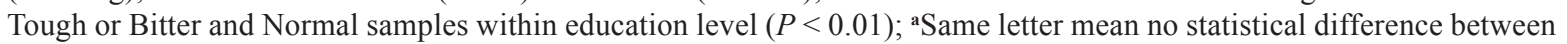
tender and tough samples $(P=0.23) ;{ }^{\mathrm{c}, \mathrm{d}}$ Different letters mean statistical difference within Normal samples among education level $(P<0.06)$; Number of untrained consumers in the sensory evaluation (elementary $=35$, middle $=98$, college $=173)$; *Numbers inside bars are Standard Error of Mean. 

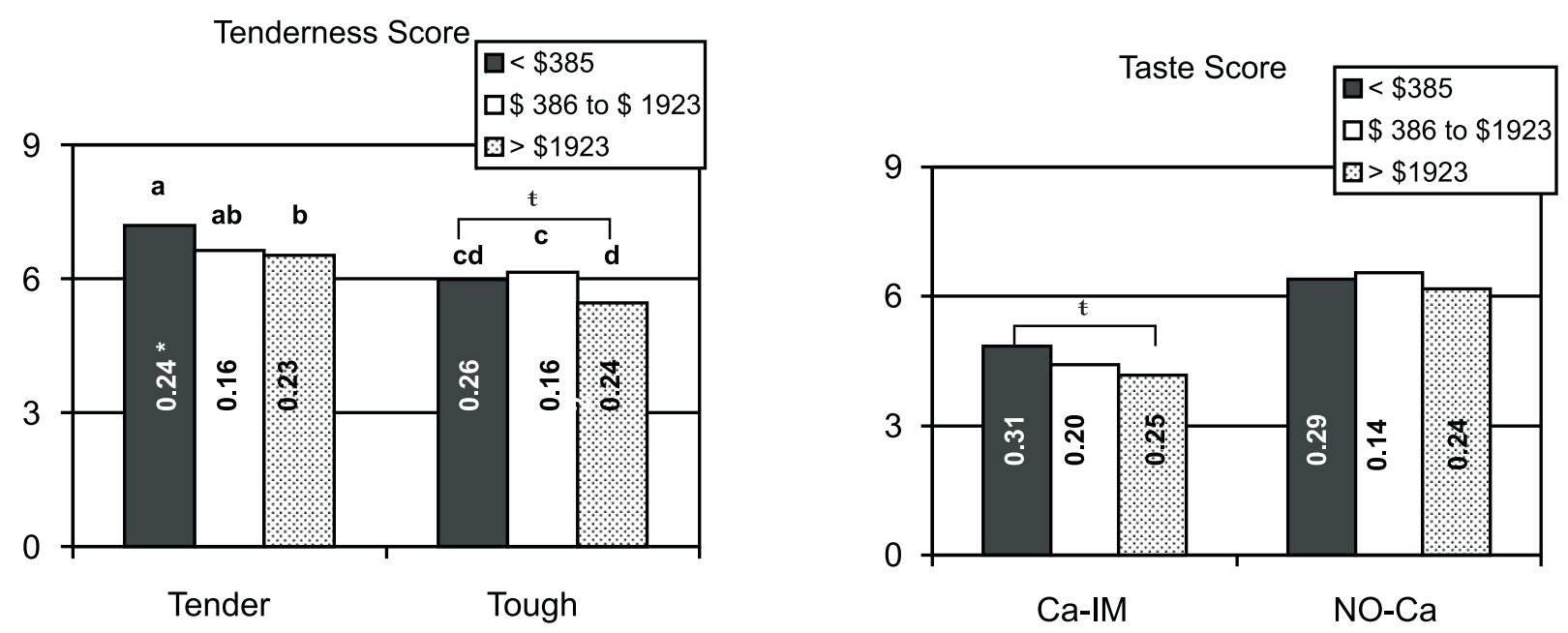

Figure 6 - Income (US dollar month $\left.{ }^{-1}\right)$ effect on consumer tenderness $(1=$ extremely tough; $9=$ extremely tender) and taste scores $(1=$ dislike extremely; $9=$ like extremely) of strip loin varying in tenderness and taste. Tenderness $=$ Tender $(\leq 4.1 \mathrm{~kg})$ and Tough $(\geq 4.8 \mathrm{~kg})$; Taste $=\mathrm{Ca}-\mathrm{IM}$ steaks $($ Bitter $)$ and NO-Ca (Normal); ${ }^{\mathbf{t}}$ Statistical differences in the scores given to Tender and Tough or Bitter and Normal samples within income $(P \leq 0.01)$; ${ }^{\text {abb }}$ Different letters mean statistical difference within Tender samples among income $(P=0.10)$; Number of untrained consumers in the sensory evaluation $(<$ US $\$ 385=71 ; \$ 386$ to $1923=154 ;>\$ 1923=77) ; *$ Numbers inside bars are Standard Error of Mean.

dents and young professionals graduated recently from college, which would only show higher requirement (lower scores), comparable to consumers of the high income level, in meat with tenderness problems (tough). Income seems to be less important than cultural background, including the accessibility to meat consumption.

Reported are somehow different from those observed elsewhere, since in the US there were no differences in tenderness scores given to steaks of distinct shear force (tender, intermediate, and tough) by consumers from families at a wide range of income levels (Barham et al., 2003). Furthermore, the income level did not influence the likelihood of consumers to prefer tender or tough steaks (Lusk et al., 2001).

A correlation was found between meat tenderness and taste. The equation that would describe the tenderness evaluation of normal taste samples was: TENDERNESS SCORE $=2.6+0.6$ TASTE SCORE $(\mathrm{R}=$ $0.57 ; P<0.01)$. This is an indication of crossed effect of those attributes (i.e., tenderness and taste) in sensorial evaluation of meat by consumers, and that taste is an important component of tenderness evaluation by Brazilian consumers. High correlations between flavor and tenderness scores revealed this same confounding effect for meat sensory evaluation by Australian consumers (Thompson, 2004).

\section{CONCLUSIONS}

Brazilians who have access to beef consumption are able to perceive tender from tough beef when eating samples of different WBS force, even when those differences are in low range of tenderness variation within a threshold of slightly tender to tough meat. The consumers are also able to perceive uncharacteristic taste. The perception of those palatability attributes is dependent to some degree of consumers gender, age, education and income level.

\section{ACKNOWLEDGEMENTS}

We would like to thank SVCex (Culture and Extension Services) of ESALQ, and the support given by the meat plant companies Frigoríficos Angelelli Ltda and Frigol Ltda., and FEALQ foundation.

\section{REFERENCES}

AMERICAN MEAT SCIENCE ASSOCIATION - AMSA. Research guidelines for cookery, sensory evaluation and instrumental tenderness measurements of fresh meat. Savoy, 1995.

BARHAM, B.L.; BROOKS, J.C.; BLANTON JR., J.R.; HERRING, A.D.; CARR, M.A.; KERTH, C.R.; MILLER, M.F. Effects of growth implants on consumer perceptions of meat tenderness in beef steers. Journal of Animal Science, v.81, p.3052-3056, 2003.

BOLEMAN, S.J.; BOLEMAN, S.L.; MILLER, R.K.; TAYLOR, J.F.; CROSS, H.R.; WHEELER, T.L.; KOOHMARAIE, M.; SHACKELFORD, S.D.; MILLER, M.F.; WEST, R.L.; JOHNSON, D.D.; SAVELL, J.W. Consumer evaluation of beef of known categories of tenderness. Journal of Animal Science, v.75, p.15211524, 1997.

BROOKS, J.C.; BELEW, J.B.; GRIFFIN, D.B.; GWARTNEY, B.L.; HALE, D.S.; HENNING, W.R.; JOHNSON, D.D.; MORGAN, J.B.; PARRISH JR., F.C.; REAGAN, J.O.; SAVELL, J.W. National Beef Tenderness Survey-1998. Journal of Animal Science, v.78, p.1852$1860,2000$.

DRANSFIELD, E. Beef - What price for tenderness? Meat International, v.7, p.24-27, 1997. 
DRANSFIELD, E.; ZAMORA, F.; BAYLE, M.-C. Consumer selection of steaks as influenced by information and price index. Food Quality and Preference, v.9, p.321-326, 1998.

DUGAN, M.E.R.; AALHUS, J.L. Beef tenderness: within longissimus thoracis et lumborum steak variation as affected by cooking method. Canadian Journal of Animal Science, v.78, p.711-714, 1998.

EGAN, A.F.; FERGUSON, D.M.; THOMPSON, J.M. Consumer sensory requirements for beef and their implications for the Australian beef industry. Australian Journal of Experimental Agriculture, v.41, p.855-859, 2001.

FILLION, L.; KILCAST, D. Food texture and eating difficulties in the elderly. Food Industry Journal, v.4, p.27-33, 2001.

HUFFMAN, K.L.; MILLER, M.F.; HOOVER, L.C.; WU, C.K.; BRITTIN, H.C.; RAMSEY, C.B. Effect of beef tenderness on consumer satisfaction with steaks consumed in the home and restaurant. Journal of Animal Science, v.74, p.91-97, 1996.

INSTITUTO BRASILEIRO DE GEOGRAFIA E ESTATÍSTICA IBGE. Pesquisa Nacional por Amostra de Domicílios, v.24, p.1120, 2003. Available in: http://www.ibge.gov.br/home/estatistica/ populacao/trabalhoerendimento/pnad2003/brasilpnad2003.pdf. Accessed in: Sept. 06, 2004.

JOHNSON, D.D.; HUFFMAN, R.D.; WILLIANS, S.E.; HARGROVE, D.D. Effects of percentage Brahman and Angus breeding age-season of feeding and slaughter end point on meat palatability and muscle characteristics. Journal of Animal Science, v.68, p.1980-1986, 1990.

KIMURA, S. Taste and nutrition. Nutrition Reviews, v.50, p.427-433, 1992.

LUSK, J.L.; FOX, J.A.; SCHROEDER, T.C.; MINTERT, J.; KOOHMARAIE, M. In-store valuation of steak tenderness. American Journal of Agricultural Economics, v.83, p.539-550, 2001.

McKEITH, F.K.; DEVOL, D.L.; MILES, R.S.; BECHTEL, P.J.; CARR, T.R. Chemical and sensory properties of thirteen major beef muscles. Journal of Food Science, v.19, p.241-248, 1985.

MILLER, M.F.; GUERRA, A.L.; RAMSEY, C.B.; BRITTIN, H.C. Determination of threshold for beef tenderness by consumer. In: RECIPROCAL MEAT CONFERENCE, 46., Lincoln, 1993. Proceedings. Savoy: American Meat Science Association and National Livestock and Meat Board, 1993. p.69.

MILLER, M.F.; HOOVER, L.C.; COOK, K.D.; GUERRA, A.L.; HUFFMAN, K.L.; TINNEY, K.S.; RAMSEY, C.B.; BRITTIN, H.C.; HUFFMAN, L.M. Consumer acceptability of beef steak tenderness in the home and restaurant. Journal of Food Science, v.60, p.963965, 1995

MILLER, M.F.; CARR, M.A.; RAMSEY, C.B.; CROCKETT, K.L.; HOOVER, L.C. Consumer thresholds for establishing the value of beef tenderness. Journal of Animal Science, v.79, p.3062-3068, 2001.

MILLER, R. Assessing consumer preferences and attitudes toward meat and meat products. Brazilian Journal of Food Technology, v.6, p.6780, 2003. Special issue.

MORGAN, J.B.; MILLER, R.K.; MENDEZ, F.M.; HALE, D.S.; SAVELL, J.W. Using calcium chloride injection to improve tenderness of beef from mature cows. Journal of Animal Science, v.69, p.4469-4476, 1991.

NEELY, T.R.; LORENZEN, C.L.; MILLER, R.K.; TATUM, J.D.; WISE, J.W.; TAYLOR, J.F.; BUYCK, M.J.; REAGAN, J.O.; SAVELL, J.W. Beef customer satisfaction: role of cut, USDA quality grade, and city on in-home consumer ratings. Journal of Animal Science, v.76, p.1027-1032, 1998.
PÉREZ, M.L.; ESCALONA, H.; GUERRERO, I. Effect of calcium chloride marination on calpain and quality characteristics of meat from chicken, horse, cattle and rabbit. Meat Science, v.48, p.125134, 1998.

QUAGRAINIE, K.K.; UNTERSCHULTZ, J.; VEEMAN, M. Effects of product origin and selected demographics on consumer choice of red meats. Canadian Journal of Agricultural Economics, v.46, p.201-219, 1998 .

ROININEN, K.; LÄHTEENMÄKI, L.; TUORILA, H. Quantification of consumer attitudes to health and hedonic characteristics of foods. Appetite, v.33, p.71-88, 1999.

SAVELL, J.W.; SHACKELFORD, S.D. Significance of tenderness to the meat industry. In: RECIPROCAL MEAT CONFERENCE, Knoxville, 1992. Proceedings. Savoy, 1992. v.45, p.43-46.

SAVELL, J.W.; BRANSON, R.E.; CROSS, H.R.; STIFFLER, D.M.; WISE, J.W.; GRIFFIN, D.B.; SMITH, G.C. National consumer retail beef study: palatability evaluations of beef loin steaks that differed in marbling. Journal of Food Science, v.52, p.517-519, 1987.

SHACKELFORD, S.D.; WHEELER, T.L.; MEADE, M.K.; REAGAN, J.O.; BYRNES, B.L.; KOOHMARAIE, M. Consumer impressions of tender select beef. Journal of Animal Science, v.79, p.2605-2614, 2001.

SPSS FOR WINDOWS. Statistical software. Release 11.0.0 Standard version. London: SAGE, 2001.

TEPPER, B.J.; STOERR, A. Chemosensory changes with aging. Trends in Food Science and Technology, v.2, p.244-246, 1991.

THOMPSON, J.M. The effects of marbling on flavor and juiciness scores of cooked beef, after adjusting to a constant tenderness. Australian Journal of Experimental Agriculture, v.44, p.645-652, 2004.

UMBERGER, W.J.; FEUZ, D.M.; CALKINS, C.R.; KILLINGERMANN, K. U.S. consumer preference and willingness-to-pay for domestic corn-fed beef versus international grass-fed beef measured through an experimental auction. Agribusiness, v.18, p.491504, 2002.

WHEELER, T.L.; SHACKELFORD, S.D.; JOHNSON, L.P.; MILLER, M.F.; MILLER, R.K.; KOOHMARAIE, M. A comparison of WarnerBratzler shear force - Assessment within and among institutions. Journal of Animal Science, v.75, p.2423-2432, 1997.

WHEELER, T.L.; VOTE, D.J.; LEHESKA, J.M.; SHACKELFORD, S.D.; BELK, K.E.; WULF, D.M.; GWARTNEY, B.L.; KOOHMARAIE, M. The efficacy of three objective systems for identifying beef cuts that can be guaranteed tender. Journal of Animal Science, v.80, p.3315-3327, 2002.

WHEELER, T.L.; SHACKELFORD, S.D.; KOOHMARAIE, M. The accuracy and repeatability of untrained laboratory consumer panelists in detecting differences in beef longissimus tenderness. Journal of Animal Science, v.82, p.557-562, 2004.

WYLE, A.M.; VOTE, D.J.; ROEBER, D.L.; CANNELL, R.C.; BELK, K.E.; SCANGA, J.A.; GOLDBERG, M.; TATUM, J.D.; SMITH, G.C. Effectiveness of the SmartMV prototype BeefCam system to sort beef carcasses into expected palatability groups. Journal of Animal Science, v.81, p.441-448, 2003.

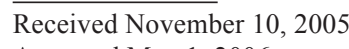

Accepted May 1, 2006 